Kohl: a Journal for Body and Gender Research

Vol. 4, No. 1 (Summer 2018)

\title{
State Policing: Moral Panics and Masculinity in post-2011 Egypt
}

\author{
Mariam Mecky
}

\begin{abstract}
:
This article explores the interplay of the politics of moral panics, hegemonic state discourses, and the notion of masculinity in Egypt after the 2011 uprising. As sexual violence in the public sphere has become more visible in Egyptian mainstream public discourse post-2011, the state narrative was often anchored in morality and stability. Through examining three incidents of sexual violence, I attempt to unpack the state rhetoric that aims to police bodies, deeming certain female bodies violable, and vilifying male and female subjectivities. Through the logic of the masculinist state, I examine how the Egyptian state polices women's bodies and consolidates male sexual dominance over women, using the politics of moral panics. The state, I argue, aims to reinforce its hegemonic masculinity to maintain control over the gendered public sphere and eliminate prospects of socio-political change, thereby consolidating the gendered architecture of citizenship.
\end{abstract}


A few days following his inauguration, the Egyptian President Abdel-Fatah El-Sisi said that "sexual harassment is an alien behaviour to Egyptian culture," calling on Egyptians to restore "the moral spirit" of society (Ahram Online, 2014a). These remarks came after El-Sisi visited a survivor of sexual violence, who was a victim of mass sexual assault on the eve of his inauguration, at the hospital, apologized to her, and brought her a flower bouquet. Since the 2011 popular uprising against former authoritarian president Hosni Mubarak, moral panics have dominated the Egyptian public discourse, especially when it comes to gendered dynamics. Moral panics, as defined by Weeks (2003) in the early 1980s, is a state of distress that is directed towards a certain group violating social values and centered around sexuality mostly "in situations of confusion and ambiguity" (2003; 101). Developing the term, Rubin (1984) defines moral and sex panics as a "political moment of sex, in which diffuse attitudes are channeled into political action and from there into social change," (163) while the state and the media instigate a public outcry on matters related to sexuality, bodily integrity, and morals. It also centers a group as a threat to public morality, with laws often enacted as a result. Moreover, the political system and patriarchal configuration of the sexual system are not monolithic, and neither are states; in fact, such a system takes different forms (Rubin, 1984; 161). Using this conceptualization, the Egyptian state has instigated a state of social anxiety and panic towards bodies of female protestors, deeming them degenerate, sexually deviant, and inviolable. This narrative, in turn, serves to vilify male and female subjectivities.

Hence, this article tackles the interplay of the politics of moral panics, hegemonic state discourses, and the notion of masculinity in Egypt post-2011. It aims to examine how the Egyptian state attempts to consolidate its grip on hegemonic and subordinate masculinities, whereas policing of women's bodies and consolidating of male sexual dominance over women maintains the state's hegemonic control over the gendered public sphere. The first section of this article explores the literature on the notion of masculinity, specifically in relation to nationalism in gendered state-security dynamics. The second section tackles the contextualization of state sexual violence in Egypt. The third section reviews the politics of moral panics with regards to the hypervisibility of three incidents of sexual violence and the state narrative post-2011: one incident took place a couple of months after the $25^{\text {th }}$ of January uprising, when female protestors were subjected to forced virginity tests by army personnel. Another incident, publically referred to as the "Girl with the Blue Bra" in mainstream media, occurred when a woman was stripped of her clothes by security forces in December 2011. The last incident was the mob sexual assaults that took place on the eve of the inauguration of El-Sisi as president. These incidents were all characterized by hypervisibility in the media, heightened role of the state, and intensified reactions, as they took place in the wake of the Egyptian revolution. I recall the outrage of my friends and my own, and the uproar expressed on social media platforms, faced by the disparity in and audacity of the state rhetoric and state-sponsored media coverage of these incidents. Through the conceptualization of moral panic as a state rhetoric, this article examines how the logic of masculine state is reconsolidated alongside the idea of women as bearers of national identity, and in turn reproduces notions of an honorable nation, a respectable woman, a proper man, and critically violable bodies. 


\section{State, Masculinity, and the Nation}

The construction of masculinity in Egypt is indisputably multi-layered. Sociopolitical dynamics play an instrumental role in the context of an increased militarization of the state. Egypt has been witnessing an unstable political and economic transition since the popular uprising in 2011. The Supreme Council for Armed Forces (SCAF) held power after former president Hosni Mubarak was overthrown, following 18 days of mass protests nationwide. In 2012, the first president Mohamed Morsi, affiliated with the Muslim Brotherhood group, was elected. On July 3, 2013, defense minister in Morsi's government Abdel-Fatah El-Sisi, announced the overthrow of Morsi in a televised statement, representing the army. Thereby per the constitution, the president of Constitutional court, Adly Mansour, was instated interim president. In June 2014, El-Sisi won the presidential elections, assuming power (Maher, 2014). Since 2011, there have been aspirations for media reform. However, both state and privately-owned media greatly support the current regime. As Abdulla (2014) notes: "State media remain in the service of the regime rather than the people. Private satellite channels primarily serve the interests of the businesspeople that own them, most of whom were closely allied with the old Mubarak regime and seem to be adamantly behind the current regime of President Abdel Fattah el-Sisi." 1 Thus, the media has played a central role in predominantly conveying state discourses and attacking the narratives of any opposition.

While states or state powers are hardly monolithic or uniform, they are often regarded as masculinist (Brown, 1984; Yuval-Davis, 1997). Without pursuing "men's interests" deliberately or explicitly, state powers are argued to be a "historical product and expression of male predominance in public life and male dominance generally, state power itself is surely and problematically gendered" (Brown, 1984; 12). Moreover, states often present themselves as masculine, where their masculine identity is shaped in relation to women as bearers of the nation. Women in nationalist movement are frequently treated by political elites as symbols of the nation (Enloe, 2014). The same applies in nationalist discourse at times of conflict or uprisings. Female citizens are reduced to their bodies, which are in turn treated as sites of contestation. In relation to that, the masculine identity is constructed and reproduced. As Cornwall \& Lindisfarne (1994) argued, the social construction of masculinity is made in relation to femininity, and cannot be in abstract, whereas the social construction of sexuality is established as binaries that consolidate the heteronormative patriarchal hierarchies of societies, and that simultaneously reinforce hegemonic masculinity. Hegemonic masculinity is defined as "how particular groups of men inhabit positions of power and wealth and how they legitimate and reproduce the social relationships that generate their dominance" (Carrigan et al., 1985; 92, cited in Cornwall \& Lindisfarne, 1994; 19). Lindisfarne (2017) demonstrated how men are often regarded as weak, dishonorable, shameful, or even feminized if they do not "control women's behavior," losing their "credibility" as men (85). In her book on the notion of masculinity in Egypt and thresholds that shape the relationship between embodiment and masculinity at Al-Zawiyya, an underprivileged socio-economic neighborhood in Cairo, Ghannam (2013) examined the notion of "ideal man" and gendered subjectivities as constructed through the embodiment of certain social norms. As she puts it, the ideal or "proper" man is not shaped by

\footnotetext{
${ }^{1}$ For more please see Rasha Abdulla, R. (2014). "Egypt's Media in the Midst of Revolution." Carnegie Endowment for International Peace. Available at: http://carnegieendowment.org/2014/07/16/egypt-s-media-in-midst-of-revolution/hg1v
} 
differentiating "manly" qualities from "womanly" ones, but through a dynamic process "of doing and being man." This process is not a static construction of masculinity; rather, it is continuous, with social interactions attempting to maintain social norms (Ghannam, 2013; 56). In that sense, the state constructs its discourse around masculinity through the gendered embodiment of women, thus reinforcing hegemonic masculinity.

In relation to the masculinist state, Egypt as a nation has been constructed in mainstream public discourse as a feminized subject, a woman whose honor must be defended. Therefore, the masculinist state aims to guard the feminine nation to protect its honor. Since the late nineteenth century, Egyptian nationalists appropriated the concept of family honor and centered it on female purity to the nation. National honor, in this context, was developed in the struggle against colonialism and imperial intervention (Baron, 2004). Simultaneously, women were constructed as mothers of the nation, while the nation was depicted as a collective issue that concerns patriarchal families as well as women; hence, women are expected to uphold values of honor and purity (Hafez, 2014a). Although women are assigned as bearers of the nations, they are only given an object status rather than that of an active citizen; they are disregarded from the "body politic" (Al-Ali, 2009) and constructed as symbols of the nation who are in need of "protection." Body politic is often used as a spatial metaphor for a common political and social space, in this case, between a human body and a polity (Brown \& Rasmussen, 2006). As Mikadishi (2014) accurately remarks in the Lebanese context, there is an "uneven distribution of national identity and honour across gendered divide." It is similar in the Egyptian context where the nation's honor is drawn from the female honor, which is particularly visible at the heightened time of what Egyptian public discourse refers to as a revolution. This discourse has been reflected in the construction and reproduction of masculine identity. Exemplifying this is the call of an Egyptian activist, Asmaa Mahfouz, in a viral video for men to join the protests of the $25^{\text {th }}$ of January. Addressing men, she said, "show your honour and manhood and come," adding that if one thinks women should not go to Tahrir square because they will be assaulted, they should then come to protect her and any girl who plans to protest. (Mahfouz, 2011, cited in Amar, 2011; 301; Ghannam, 2013; 1). ${ }^{2}$ This narrative suggests that women are in need of masculine paternal protection to access the public sphere; it also asserts and consolidates an exceedingly problematic yet popular nexus of manhood, women, and honor in the form of a paternal relation. The public discourse emphasizes that males should protect women's sexuality in order to be "men." As the Egyptian nation has been often represented in popular discourse as a female that should be "protected," popular discourse made parallels between a proper state leadership and a proper man: he thus becomes the safeguard, provider of "protection" (Ghannam, 2013; 163). Therefore, the state rhetoric builds on asserting that women's sexuality must be "protected" to preserve the country's honor, identity, and morality. In other words, the lack of women's sovereignty over their bodies becomes a prerequisite for an "honorable nation." Protection of women's honor is a mainstay of masculinity, which is what Enloe (2014) refers to as "patriarchal nationalisms."

2 Translated excerpt of Mahfouz's call from Arabic by Amar (2011) and Ghannam (2013). 


\section{Sexual Violence and Politics of Respectability}

While sexual violence against women by state and individual actors has existed previously in Egypt, it became more visible in mainstream public discourse after 2011 (Skalli, 2014). Sexual violence in the public sphere, in the context of demonstrations, increasingly targeted women and girls, who got attacked by groups of men and boys (Abouelnaga, 2016; Al-Ali, 2012; Hafez, 2014a; Hafez, 2014b; Tadros, 2014; Tadros, 2016). State authorities neither prevented those attacks, nor protected the protestors; not only did they not hold the perpetrators accountable, but they were responsible for these attacks in some instances (FIDH et al., 2014; Nazra et al., 2014). A joint NGO report asserts that "women protesters were repeatedly targeted by security and armed forces" during the SCAF rule after the 25 January (FIDH et al., 2014; 10-11). In addition, as Al-Ali $(2012 ; 29)$ pointed out, security forces treated female protesters differently from their male counterparts, in that harassment and police brutality take a sexual form: from being stripped naked, to being photographed, to being accused of engaging in sex work.

Through collective mobilization, NGOs and youth initiatives were able to arrange rescue operations for survivors of mob assaults, document such violations, and criticize the government's compliancy and responsibility (Tadros, 2014). Meanwhile, the women and men who took part in these rescue initiatives were also the targets of politically motivated sexual violence, although men's experiences were not under the spot light (Tadros, 2016). 250 cases of politically motivated mob sexual assaults targeting women by men and boys have been documented from November 2012 to July 2013 in Tahrir Square, the center of protests in Cairo, during the presidency of Morsi (FIDH et al., 2014). Attacks targeting women in the proximity of Tahrir square had a certain pattern, "where group of men assault women who are alone or the attackers try isolate women away from their colleagues while number of aggressors rapidly increase, they drag the victim into a circle of large gatherings" (Egyptian Center for Women's Rights, 2014). The women are groped, dragged violently, sometimes undressed, with "several" cases leading to rape. (FIDH et al., 2014; 11). Some activists referred to these kind of attacks as "the circle of hell" to describe how the mob of boys and men circle the survivor as they attack her. In the June 30th protests that led to Morsi's ouster, 101 cases of sexual violence, including 3 rape cases, were documented around Tahrir Square (16). After the overthrow of Morsi in July 2013, mob assaults reportedly persisted; an attack was showcased on live television during a protest coverage on the third anniversary of the January 25 uprising (FIDH et al., 2014). Between June 2012 and June 2014, organizations have documented over 500 cases of gang rape and sexual assaults (Nazra et al., 2014). Meanwhile, the authorities did not hold anyone accountable for any of these cases, nor were there any official statistics available on mass assaults or gang rapes. Politically motivated sexual assault is not a new instrument by the Egyptian authorities; it has been used against female protestors during the former regimes, most notably in 2005, during the incident widely known as "Black Wednesday." During a protest calling for the boycott of a constitutional reform referendum, security forces opened the way for groups of men to assault female journalists participating in the protest. A policeman reportedly told female protesters that these attacks are meant to "stop you taking part in demonstrations again" (FIDH et al., 2014).

Following the $25^{\text {th }}$ of January, a number of sexual assault incidents prompted a state rhetoric anchored in morality. Political discourse in response to the surge of sexual violence was centered on blaming the victim, 
relaying the message in the media that women should not take part in "public spaces" (FIDH et al., 2014). For instance, Major General Adel Afifi, a member of the Shura Council Human Rights Commission, said in February 2013: "the girl who knows that she will be among thugs must protect herself before asking that the police protect her while police officers cannot protect themselves.. in some cases, the girl contributes [to] being raped by $100 \%$ because she put herself in these circumstances" (Egyptian Center for Women's Rights, 2014). In such dynamics, the politics of respectability play a considerable role, where some bodies are deemed respectable and others are treated as "violable." The good girl, portrayed as the middle class pious woman, is deemed respectable. The bad girl, on the other hand, is the female protestor or a sex worker - a woman who does not conform to the socially acceptable behavior of the category "woman," hence the policing of her body (Amar, 2011). However, the state, represented in the gendered security apparatus, attempts to police all bodies simultaneously, even if differently. In other words, both images of "woman" lack sovereignty over their bodies. A "good girl" deserves male protection, while a "bad girl" requires disciplining. In that process, the state creates hypersexualized, "sanctioned," and unregulated parahuman subjects to instigate moral panic, through queering certain bodies, as Amar (2011) notes. Amar (2011; 306) uses queering not as policing homosexual or non-heteronormative bodies, but as producing "subjects of social and moral panic." Parahumans are "hyper-visible" subjects of politics that security authorities deploy "while their ability to act in emancipatory ways is buried by multiple intersecting modes of sexual, cultural, moral and social fantasy and discipline" (Amar, 2011; p.306). This hypervisibility constructs mobs of hypersexualized men that the state portrays as threats to female respectability. Meanwhile, the state simultaneously commissions security forces to assault female protestors, considered "immoral" gendered subjects, and denies them any form of protection. Such discourses shed the light on the production of gendered hypervisibility; not only do they vilify the "bad girl," but working class men as well, depicting them as sex-crazed, uncontrolled subjects of terror and the only sources of violence. Through these gendered subjects, the masculine state represents these female bodies as violable and inviolable in mainstream discourse, producing a moral and sex panic. Simultaneously, the state also reproduces guardianship as an element of masculinity in relation to these bodies. In that process, it authorizes the policing of female and male non-docile bodies as a mean to preserve public morality. Sexual violence against women, then, is mobilized by the state as a tool to preserve male dominance and masculinist hegemony.

\section{Violable bodies, Respectable Women}

In March 2011, a couple of months after the $25^{\text {th }}$ of January protests, 18 female protestors were subjected to virginity tests by army personnel after being detained for four days for taking part in a demonstration. The detainees were reportedly forced to strip naked in full view of the soldiers. Samira Ibrahim, one of the detained protesters, filed an official complaint against the army. Yet, Ibrahim was defamed and accused of lying (Abouelnaga, 2016). Nevertheless, her complaint was hailed by some scholars and activists, who considered she "broke the silence" on the control of female body, and filed the case on political grounds against the army violations. In other words, she did not do so to protect her honor; she "did not claim the category of the virgin as scared place of refuge" (Seikaly, 2012, cited in Abouelnaga, 2016; 120). The military officially denied the accusations. However, later in June, El-Sisi, then director of Egypt's military intelligent and member of the 
ruling SCAF, was the first officer to publically admit the practice. He said that forced virginity tests were conducted on female protestors to "protect" the army against possible allegations of rape (Amnesty International, 2011). After the accusation, an army general, who anonymously spoke to the American TV channel CNN in May, admitted that these protestors were subjected to virginity tests and defended it: "the girls who were detained were not like your daughter or mine" (Amin, 2011). He argued that these women stayed in tents with men and were doing drugs, claiming that security forces had found Molotov cocktails and drugs in the tents. These stances exemplify a state narrative that values certain bodies that fit certain criteria; virgins and politically obedient women - the "good daughters" - are the only "respectable bodies" who could be victims of rape, and hence should be protected from rape by the military, their masculine guardians.

In the same year, the woman referred to as the "woman with the blue bra" made headlines as another infamous case of state violence. In December 2011, months after the uprising of the January 25, a young veiled woman, whose identity was concealed, was beaten and stomped on by army personnel in a sit-in against the SCAF in Tahrir square in Cairo, as her abaya, a full-length robe-like dress some Muslim women wear, was ripped off. The image of her lying down, dragged on the floor with only her blue bra and trousers showing went viral. Some people rallied to support her; a protest was held a few days later demanding the end of state violence against protestors, and the crowds chanted: "the women of Egypt are a red line" (Hafez, 2014a; Abouelnaga, 2016). Artists portrayed her in street art all over Cairo as an act of solidarity (Abouelnaga, 2016). In response to the outcry, the SCAF announced that the incident would be investigated. Nonetheless, pro-state media launched a defamatory campaign against her, from victim-blaming, slut-shaming, and questioning her virtue, to slandering protestors against the SCAF. One anchorman said: "What were you thinking wearing that abaya with nothing underneath it? And an abaya with snaps? Come on. (Hafez, 2014b; 25). Major General Adel Emara, member of the SCAF, reiterated the rhetoric that the female protestors in Tahrir are not "like your daughter or mine," challenging their morality and referring to them as "loose women." Emara reportedly said that these girls were sexually loose as they had sexual relations outside of wedlock with the young men in the square (Hafez, 2014b). This rhetoric consolidates the notion of the female protestor as an unruly subject of dissent that does not deserve protection, but that also authorizes the policing of her body. In other words, the female protestor is considered to have lost her respectability when she defies the state or her male family members - her self-assigned guardians; she becomes a violable body.

While mob assaults against women were tragically of common occurrence in protests post-2011, a state uproar over the mass sexual assault incidents against women only happened in June 2014, during the celebration of El-Sisi's inauguration as the new president. Some incidents were recorded and went viral on social media. In response, El-Sisi visited one of the survivors in the hospital and apologized to her and all "Egyptian women," promising stronger measures against the issue (Ahram Online, 2014a). El-Sisi issued a statement to denounce the incident, and a vast media campaign joined the state rhetoric in instigating moral panics. Two days after the incidents, the then-interim president Adly Mansour amended the law, criminalizing sexual harassment and defining it for the first time in the Egyptian legal framework (Ahram Online, 2014b). While the criminalization reflects over a decade of tremendous advocacy efforts and collective organization of Egyptian women's organization (Tadros, 2014), the state capitalized on it, evoking male guardianship on women's bodies. After a couple of years of state retreat and lack of accountability, El-Sisi's remarks 
suggested that women are in need of masculine male protection, unlike those female protestors who were deemed as "violable bodies." His statement also attributed rape or sexual violence at large to alien, foreign, or strange behavior, thereby disassociating Egypt, the mother nation, from those vulgar "others." Within this rhetoric, sexual violence was deliberately labelled as an "alien phenomenon" instead of systematic violence that Egyptian women struggled against for decades. This evokes Ahmed's (2000) analysis of the production of certain subjects as strange through bodily encounters and bodily integrity. She argues: "The strange body is constructed through a process of incorporation and expulsion - a movement between inside and outside, which renders that the stranger's body has already touched the surface of the skin that appears to contain the body-at-home" (54). Through Ahmed's conceptualization, the state rhetoric constructs certain bodies - in this case, alien harasser and non-masculine bodies - as strange, maintaining the binary of violable and inviolable bodies. In that process, a certain class of men is vilified as the harasser "other," deemed nonmasculine. Meanwhile, female protestors and their male counterparts continue to be demonized in an effort to other and police unruly bodies.

In its continuous and relentless process of othering non-docile bodies, the Egyptian state orchestrated a crackdown on Egyptian queers after the rainbow flag was raised during the concert of a Lebanese band, Mashrou' Leila, in Cairo. Since September 2017, over 80 people were reportedly arrested and 40 individuals were sentenced to prison, according to Human Rights Watch (Ghoshal, 2018). Homosexuality is not explicitly criminalized by Egyptian law; nonetheless, homosexuals have been often arrested under charges of debauchery and violation of public morality (Ahram Online, 2017). Referring to the infamous queen boat case that saw 52 homosexual men arrested on a boat and tried for debauchery and immorality, Pratt (2007) argued for "not only the significance of gender in national identification processes but also of sexuality as a means of securing gender identities and relations within a context of shifting gender roles" (143). In the state's attempt to instigate moral panics to consolidate its power, neither heterosexual nor homosexual bodies escape its policing of non-conforming, non-docile bodies.

\section{Conclusion}

In cases of the forced virginity tests by army personnel, the girl with the blue bra, and the inauguration eve. the state constructed itself as the masculine guardian through gendered subjectivities and embodiment. Considering these incidents as manifestations of transgressions against women also leads us to question the gendered architecture of identity and citizenship. Although the three cases are incidents of sexual violence against women by state agents and individual actors, the state only condemned the violence instigated by individual actors using a moral panic narrative of respectable women, inviolable bodies, "alien to our culture," and stranger others. This incident, hence, evoked the notion of state protection for "good women." Meanwhile, violence instigated by state actors is justified as retaliation to lack of morality and stability. The women are presented as unruly non-docile bodies that defy social norms and moral values, and hence require discipline. Thus, women's bodies are not only used as sites of "contestation" by the political forces, but as sites for "masculinist" domination and "moral hegemony" as well (Hafez, 2014b). 
Through its rhetoric, the state did not only defame the female protestors but also the men, demonizing and denigrating them as violent, sex-crazed, or unmanly males, reproducing the trope of parahuman subjects. One of Tadros's interlocutor, who has been sexually assaulted while attempting to rescue a female survivor in a protest, said: "when we intervene to save women being assaulted, we find men assaulting us. . . in the middle of these confrontations, it is intended to humiliate and demoralize us" (2016; 333). In this hypervisibility of parahuman subjects, the state challenges the masculinity of male counterparts or their male relatives for not having acted as the "patriarchal guardians of women protesters;" for not protecting their "honor," they are deemed "unmanly." In other words, the state polices them as immoral and weak men who could not take care of "their female counterparts," Hence, by considering certain bodies inviolable, the state assigns men the role of protectors that "save women" from loose morality, lest they lose their own credibility and honor. In the process of constructing "proper, masculine men," the state consolidates its self-construction as the guardian of moral values and national identity, reinforcing in turn its hegemonic masculinity. Such narrative shows a masculinist state threatened by its loss of control over the public gendered space, which represents an opportunity for socio-political change. In response to the ongoing re-negotiation of gender relations in the public-private spheres in Egypt, women have become agents of transformation, prompting the state to use both the morality clause and the necessity of male protection. Thus, post-2011, the state has been drawing on rhetoric of morality and patriarchal norms to maintain the political and social status quo. It remains important to consider the state rhetoric in light of the major class differences, economic instability after the uprising, and the already embedded structural inequalities in the Egyptian society. These facets, as a result, impact the notion of masculinity, state narrative, and repression on different male and female bodies. 2017 was declared the year of women by El-Sisi and the same rhetoric continues to be reproduced by the state in the public discourse. Moral panics and sex panics have been consolidated as tools that are part and parcel of state violence, and that serve to assert sociopolitical control and consolidation of the masculine state power over any agents of transformation. 


\section{References}

Abouelnaga, S. (2016). Women in Revolutionary Egypt: Gender and the New Geographies of Identity. Cairo: The American University in Cairo Press.

Abdullah, R. (2014). "Egypt's Media in the Midst of Revolution." Carnegie Endowment for International Peace. Available at: http://carnegieendowment.org/2014/07/16/egypt-s-media-in-midst-of-revolution/hg1v (Last accessed 16 April 2018)

Al-Ali, N. (2009). "Up Against Conceptual Frameworks: Post-Orientalism, Occidentalism and Presentations of the Self." Secularism, Gender and the State in the Middle East: The Egyptian Women's Movement. United Kingdom: Cambridge University Press. 19-50.

Al-Ali, N. (2012). "Gendering the Arab Spring." Middle East Journal of Culture and Communication 5.1: 2631.

Ahmed, S. (2000). Embodying Strangers In Strange Encounters: Embodied Others in Post-Coloniality. London and New York: Routledge. 38-54

Ahram Online. (2014a). "El-Sisi visits Tahrir sexual assault victim, apologises to Egypt's women." Available at: http://english.ahram.org.eg/NewsContent/1/0/103444/Egypt//E/Sisi-visits-Tahrir-sexual-assaultvictim,-apolog.aspx (Last accessed 15 January 2017)

Ahram Online. (2014b). "Egypt's Mansour issues law for tougher sexual harassment penalties." Available at: http://english.ahram.org.eg/NewsContent/1/0/103010/Egypt/0/Egypts-Mansour-issues-law-fortougher-sexual-haras.aspx (Last accessed 15 January 2017)

Ahram Online. (2017). "Two more arrested for allegedly raising rainbow flag at pop concert in Cairo." Available at: http://english.ahram.org.eg/NewsContent/1/64/278140/Egypt/Politics-/-Two-morearrested-for-allegedly-raising-rainbow-f.aspx (Last accessed 5 February 2017)

Amar, P. (2011). "Turning the Gendered Politics of the Security State Inside Out? Charging the Police with Sexual Harassment in Egypt." International Feminist Journal of Politics 13. 3: 299-328.

Amnesty International. (2011). "Egypt: Military Pledges to Stop Forced 'Virginity Tests'." Available at: https://www.amnesty.org/en/press-releases/2011/06/egypt-military-pledges-stop-forced-virginitytests/ (Last accessed 15 January 2017)

Amin, S. (2011). "Egyptian general admits 'virginity checks' conducted on protesters." Available at: http://edition.cnn.com/2011/WORLD/meast/05/30/egypt.virginity.tests/index.html (Last accessed 15 January 2017)

Brown, W. (1992) "Finding the man in the state." Feminist Studies 18.1: 7-34.

Brown, M., \& Rasmussen, C. (2006). "The Body Politic as Spatial Metaphor." Citizenship Studies 9.5: 469484.

Cornwall, A., \& Lindisfarne, N. (1994). "Dislocating Masculinity: Gender, Power and Anthropology." Dislocating masculinities: Comparative ethnographies. London and New York: Routledge. 11-47.

Egyptian Center for Women's Rights. (2014). "Out of a Gunpowder barrel: Egyptian Women's Status Report in 2013." Available at: http://ecwronline.org/?p=4578 (Last accessed on 16 April 2018)

Enloe, C. (2012), "Masculinities, Policing, Women, and International Politics of Sexual Harassment." International Feminist Journal of Politics 15.1: 77-81. 
Enloe, C. (2014). Bananas, Beaches and Bases: Making Feminist Sense of International Politics. $2^{\text {nd }}$ Ed. University of California Press.

FIDH, Nazra for Feminist Studies, New Women Foundation, \& Uprising of Women in the Arab World. (2014). "Egypt: Keeping women out. Sexual violence against Women in the Public Sphere." Available at: http://nazra.org/sites/nazra/files/attachments/joint_report_sexual_violence_egypt_en.pdf (Last accessed on 16 April 2018)

Ghannam, F. (2013). In Live and Die like a Man: Gender Dynamics in Urban Egypt. Stanford: Stanford University Press.

Ghoshal, N. (2018) "More Arrests in Egypt's LGBT Crackdown, but No International Outcry." Human Rights Watch. Available at: https://www.hrw.org/news/2018/01/22/more-arrests-egypts-lgbt-crackdown-nointernational-outcry (Last accessed 17 February 2018)

Hafez, S. (2014a). Bodies That Protest: The Girl in the Blue Bra, Sexuality, and State Violence in Revolutionary Egypt. University of Chicago Press. 20-28.

Hafez, S. (2014b). "The revolution shall not pass through women's bodies: Egypt, uprising and gender politics. The Journal of North African Studies 19.2:172-185.

Lindisfarne, N. (2017). "Variant Masculinities, Variant Feminities: Rethinking Honour and Shame." Dislocating Masculinities: Comparative Ethnographies. $2^{\text {nd }}$ Ed. Edited by Andrea Cornwall and Nancy Lindisfarne. London: Routledge. 78-92.

Maher, H. (2014). "From the barracks to Egypt's presidency: El-Sisi's journey towards Itihadiya." Ahram. Available at: http://english.ahram.org.eg/NewsContent/1/0/102828/Egypt/0/-From-the-barracks-toEgypts-presidency-ElSisis-jo.aspx (Last accessed 15 January 2017)

Mikdashi, M. (2014, February). "Moral Panics, Sex Panics and the Production of A Lebanese Nation." Jadaliyya. Retrieved from. http://www.jadaliyya.com/Details/30261/Moral-Panics,-Sex-Panics-andthe-Production-of-A-Lebanese-Nation (Last accessed 15 January 2017)

Nazra For Feminist Studies \& the Center For Egyptian Women's Legal Assistance. (2014). "As part of the Events of the 16-Day Campaign for the Elimination of Violence against Women, Nazra For Feminist Studies And the Center For Egyptian Women's Legal Assistance (CEWLA) Launch 'Qanun Nashaz' For The Elimination Of Legalized Violence Against Women." Available at: http://nazra.org/en/2014/11/qanun-nashaz-elimination-legalized-violence-against-women (Last accessed on 16 April 2018)

Pratt, N. (2007). "The Queen Boat case in Egypt: sexuality, national security and state sovereignty." Review of International Studies 33: 129-144.

Rubin, G. (1984). "Thinking Sex: Notes for a Radical Theory of the Politics of Sexuality." Pleasure and Danger: Exploring Female Sexuality. Edited by Carol Vance. Boston and London: Routledge \& K. Paul. 143-178

Skalli, L. (2014). "Young women and social media against sexual harassment in North Africa." The Journal of North African Studies 19.2: 244-258.

Tadros, M. (2014). "The politics of mobilising for gender justice in Egypt from Mubarak to Morsi and beyond." IDS Working Papers 442: 1-35.

Tadros, M. (2016). "Challenging Reified Masculinities: Men as Survivors of Politically Motivated Sexual Assault in Egypt." Journal of Middle East Women's Studies 12.3: 323-342. 
Weeks, J. (2003). "Sexuality, Intimacy and Politics." Sexuality. London and New York: Routledge. 91-116/ Yuval-Davis, N. (1997). "Theorizing gender and nation." Gender and Nation. London: SAGE Publications. 1-

25. 